\title{
STRATEGIC PRIORITETI OF THE USE OF MANAGEMENT OF INDUSTRIAL ENTERPRISES COMPETITIVENESS
}

\author{
Tkachenko S.M. \\ Classic Private University \\ Ukraine, 69000, Zaporizhzhya, Zhukovsky str., 84 \\ space7770@ukr.net \\ ORCID: 0000-0002-3798-5902
}

Key words:

competitiveness, industrial enterprises, potential of competitiveness of enterprise, strategic management of enterprise, management conceptions, innovative competitiveness, case an innovative process frame, a competitiveness.
An estimation and strategic management of enterprise a competitiveness are investigated in the article. Considered basic conceptions of management and question of improvement of management innovations that is sent to the increase of competitiveness of enterprise. Reasonably, that the important aspect of the system of providing of the proper level of competitiveness of enterprise is a process of his evaluation, during that appear him strengths and weaknesses, hidden possibilities and potential threats, that in further gives an opportunity effectively to plan and develop activity on the basis of competitive edges. Determination of level of competitiveness of enterprise is the initial moment of planning of his activity and development of strategy of competitiveness. For functioning of organizationally-economic mechanism of providing of competitiveness of enterprise necessary system of estimation of competitiveness, that would take into account interests of investors, enterprises, consumers, state.

Attention is accented on that absence of the only understanding stipulated the core concepts of competitiveness of enterprise ambiguousness of interpretation of this category. In modern market conditions enterprises operate in a competition environment. Drawn conclusion, that for providing of effective activity to the enterprises it is needed to study a competition environment, determine competitive edges and competitiveness.

Certainly, that different approaches are to determination of competitiveness of enterprise. Drawn conclusion that competitiveness of enterprise it: comparative advantage, difference or relative description, index; property of management (subject of market relations) object to satisfy necessities; system of indexes of competitiveness and efficiency; total score of firmness of work of enterprise, effective use of resources, ability to resist or produce and sell off goods and services; ability to sustain competition at the market; touched market share; a criterion of exit of enterprise is to the commodity markets; flexibility and adaptivity; level of competense of enterprise; priority aspects of competitiveness are taking into account interests of the interested users of information about a competitiveness; quality and competitiveness of products that is produced.

Drawn conclusion, that the levers of increase of level of competitiveness of enterprise are factors of competitiveness. Establishments of determinatives of competitiveness carry out after their influence and depending on aims and tasks of management a competitiveness.

\section{СТРАТЕГІЧНІ ПРІОРІТЕТИ ВИКОРИСТАННЯ УПРАВЛІННЯ КОНКУРЕНТОСПРОМОЖНІСТЮ ПРОМИСЛОВИХ ПІДПРИЕМСТВ}

\author{
Ткаченко С.M. \\ Класичний приватний університет \\ Украйна, 69000, м. Запоріжжя, вул. Жуковського, 84
}

\begin{abstract}
Ключові слова:
конкурентоспроможність, промислові підприємства, потенціал конкурентоспроможності підприємства, стратегічне управління конкурентоспроможністю підприємства, концепції управління, інноваційна конкурентоспроможність, модель управління інноваційним процесом.
\end{abstract}

У статті досліджується оцінка та стратегічне управління конкурентоспроможністю підприємства. Розглянуті основні концепції управління і питання удосконалення управління інноваціями, що направлені на підвищення конкурентоспроможності підприємства. Обгрунтовано, що важливим аспектом системи забезпечення належного рівня конкурентоспроможності підприємства $є$ процес його оцінювання, в ході якого виявляються його сильні і слабкі сторони, приховані можливості та потенційні загрози, що у подальшому дає можливість ефективно планувати та розвивати діяльність на основі конкурентних переваг. Визначення рівня конкурентоспроможності підприємства $\epsilon$ початковим моментом планування його діяльності та розробки стратегії конкурентоспроможності. Для функціонування організаційно-економічного 
механізму забезпечення конкурентоспроможності підприємства необхідна система оцінки конкурентоспроможності, яка б врахувала інтереси інвесторів, підприємств, споживачів, держави.

Акцентовано увагу на те, що відсутність єдиного розуміння суті поняття конкурентоспроможності підприємства обумовило неоднозначність трактування даної категорії.

В сучасних ринкових умовах підприємства діють в конкурентному середовищі. Зроблено висновок, що для забезпечення ефективної діяльності підприємствам потрібно вивчати конкурентне середовище, визначати конкурентні переваги та конкурентоспроможність.

Визначено, що існують різні підходи до визначення конкурентоспроможності підприємства. Зроблено висновок що конкурентоспроможність підприємства це: порівняльна перевага, відмінність чи відносна характеристика, показник; властивість об'єкта управління (суб'єкта ринкових відносин) задовольняти потреби; система показників конкурентоспроможності та ефективності; підсумковий показник стійкості роботи підприємства, ефективного використання ресурсів, здатності протистояти чи виробляти і збувати товари і послуги; здатність витримувати конкуренцію на ринку; займана частка ринку; критерій виходу підприємства на товарні ринки; гнучкість і адаптивність; рівень компетенції підприємства; пріоритетні аспекти конкурентоспроможності з урахуванням інтересів зацікавлених користувачів інформації про конкурентоспроможність; якість і конкурентоспроможність продукції, що випускається.

Зроблено висновки, що важелями підвищення рівня конкурентоспроможності підприємства є фактори конкурентоспроможності. Встановлення визначальних факторів конкурентоспроможності здійснюють за їх впливом та в залежності від цілей і завдань управління конкурентоспроможністю.

\section{Statement of the problem}

The modern displays of new terms of competition and absence of the formed effective competition environment, low level of competitiveness, subzero capacity for innovations and subzero innovative activity, determine the necessity of rethinking of changes of control system by the subjects of menage.

Intensifying of competitive activity and globalization determine the personal touches of competition at the market of innovations that form the intensive process of fight for intellectual leadership. On the measure of forming of market relations and creation of competition environment actual are research of essence and management of enterprise a competitiveness.

\section{Analysis of recent studies and publications}

Research of competitiveness of enterprise is conducted modern authors in direction of determination of maintenance and estimation of competitiveness. To research of problems of competitiveness of enterprise the devoted labours of I. Ansoff [1], P. Dikson [4], P. Druker [5], M. Porter [7], A. Tompson and A. Striklend [9], A. Voronkova [2], R. Fatkhutdinov [10].

The question of research of forming of competitive edges of enterprise is devote different works, but providing of competitiveness and strategic management a competitiveness is needed further research.

The question of competitiveness and existent methods of her estimation finds his reflection in the advanced studies of M. Porter [11], R. Fatkhurdinov [12], A. Mazaraki [13], L. Balabanov [14], A. Levytska [15], Ye. Karpenko [16], P. Altukhova [17], I. Borysiuk, A. Yeromenko [18], D. Rybnytskyi [19], V. Litvinova [20], V. Dykan [21] but other.
A term «competitiveness» depending on the object of research it follows to distinguish competitiveness of products and competitiveness of enterprise. It is thus considered that a competitiveness of commodity is the display of competitiveness of enterprise, and the competitiveness of enterprise removes the competitiveness of country in general. Therefore important both from microeconomic and from macroeconomic positions there is exactly a competitiveness of enterprise.

The estimation of level of competitiveness of enterprise allows [22, c. 183]:

- to form administrative tasks: determination of going near a production, technology, marketing, labour resources, financing, informative and organizational providing;

- to accept an administrative decision: reduction of charges, focusing on a certain market, contracting segment;

- to work out the events of development of competitive edges : introduction of innovations, offensive events in direction of fixing of long-term advantages, protective measures in direction of warning of actions of participants, development of the program of going into new markets, bringing in of money of investor;

- to adapt an enterprise to the market conditions of menage that as a result gives victory in competitive activity for a consumer and markets of sale.

It should be noted that for today for the estimation of competitiveness of enterprise a number of methods is used.

A. Levytska suggests to examine the existent methods of estimation of competitiveness on next classification signs [15]:

- on the method of estimation (quality, quantitative);

- on a form presentation of result (matrix, graphic, index);

- after the degree of taking into account of aspects of functioning of enterprise (special, complex); 
Table 1 - Interpretation of economic category «competitiveness of enterprise»

\begin{tabular}{|c|l|}
\hline Author & \multicolumn{1}{c|}{ Determination } \\
\hline M. Porter. [11, c. 385] & $\begin{array}{l}\text { A competitiveness is property of commodity, service, subject of market relations to come } \\
\text { forward at the market at level with analogical commodities, services or competitive subjects } \\
\text { of market relations that is present at the market. }\end{array}$ \\
\hline R. Fatkhurdinov. [12, c. 23]. & $\begin{array}{l}\text { A competitiveness is property of object that is characterized the degree of the real or potential } \\
\text { satisfaction to them of certain problem, comparatively with analogical objects that are at this market. }\end{array}$ \\
\hline A. Mazaraki [13, c. 122] & $\begin{array}{l}\text { Competitiveness - represents economic relations concerning creation and realization of } \\
\text { complex of competitive edges, that inherent to the market subject. }\end{array}$ \\
\hline $\begin{array}{c}\text { L. Balabanov } \\
{[14, \text { c. } 29]}\end{array}$ & $\begin{array}{l}\text { A competitiveness of enterprise is a level of his competence comparatively with other competitors } \\
\text { on such parameters, as technology, practical skills and professional knowledge of personnel, level } \\
\text { of the strategic and current planning, politician of sale, level of management, communication, } \\
\text { quality of control system, production of goods and others like that. }\end{array}$ \\
\hline A. Levytska [15, c. 156] & $\begin{array}{l}\text { A competitiveness of enterprise is a capacity of enterprise for realization of competitive } \\
\text { edges that give an opportunity effectively to develop comparatively with other enterprises on } \\
\text { internal and external markets to him. }\end{array}$ \\
\hline
\end{tabular}

- after possibility of acceptance of strategic decisions (current, strategic);

- after direction of forming of infobase (criterion, expert);

- depending on the object of estimation (methods of estimation of competitiveness of personnel; methods of estimation of competitiveness of products; methods of estimation of competitiveness of organization);

- depending on the specified aim of estimation (of positioning in a group; determination of dynamics of positions is in a group; determination of competitive edges.

D.Yatskovyi [22] marks that depending on the degree of scope of these aspects the methods of estimation it is expedient to classify on the special and complex. The special methods are oriented to the analysis of separate parties of activity enterprises (matrix methods, method of estimation of competitiveness of products and others like that) complex (most index methods) on an all-round analysis.

\section{Objectives of the article}

The aim of the article is realization of research of essence and estimation of competitiveness of enterprise and determination of feature of providing and strategic management of enterprises a competitiveness in modern terms.

\section{The main material of the research}

The estimation of competitiveness of enterprise can terminate the contact of competitiveness of enterprise and competitiveness of products and efficiency of functioning or be based on intercommunication of competitiveness of enterprise and level of his potential and degree of influence of environment. On the basis of every approach the built methodologies of estimation of competitiveness. The competitiveness of enterprises can be certain on basis:

- matrix methods that is based on the marketing estimation of activity of enterprise and his products; methods that are base on estimation of competitiveness of products of enterprise (methods based on the theory of quality of commodity and other);

- methods that are based on the theory of effective competition with the use of structural and functional approaches;
- methods, that are based on the theories of equilibrium of firm, and methods that are based on comparative advantages;

- complex methods;

- graphic methods;

- survey of consumers, producers;

- cost methods of estimation of competitiveness.

The level of competitiveness is measured on the basis of the system of base indexes of potential of enterprise and environment and integral indexes. Before determination of competitiveness apply economical methods, hierarchically well-organized system of partial and integral indexes of competitiveness, economic and mathematical design.

Providing of competitiveness comes true on the operating, tactical and strategic levels of management. The management of enterprise a competitiveness is examined as a process of influence on the factors of competitiveness with the aim of her increase through realization of functions of estimation, analysis, planning, organization, control and account. This activity from forming of administrative decisions of achievement of leadership, strategic aims must be base on the corrected and variant types of management. Management priorities are a strategic management, development of personnel, management of enterprise flexibility as open system, forming of innovative resource of competitiveness.

Distinguish methods and facilities of permission of specific tasks of management and integration going near a management an enterprise. Modern conceptions of management is the balanced system of indexes, control system on the basis of index of EVA, management after aims, saving method, Six Sigma-mesons, Five C, system of management of quality, ICO, universal system of indexes, self-education organization. The best instruments of management of organizations are adopt the strategic planning, key competenses, segmentation of clients, survey of consumers in recent year, benchmarking, remuneration of labour on end-point, balanced system of indexes of efficiency, analysis of valueadded, outsourcing and other Majority from them sent to the improvement of strategies, providing of development, determination of markets and improvement of customer relations. To conceptions of management, the having a special purpose orientation of that is close to the task of providing of high level of competitiveness, take: 
- total quality management; reengineering of business processes;

- self-education organization; strategic management;

- organizational development.

Certain approaches improve constantly. The system of indexes that characterize activity of enterprise within the limits of conception of management a cost renovated thus: indexes of increase (Cash Flow, EPS Growth, EBIT Growth, Revenue Growth), indexes of return (ROIC, RONA/ROCE, ROE), indexes of return, increase, remaining acuests (CVA, SVA, EVA, RORAC), indexes of return, increase, remaining acuests, money stream (CFROI, TBR).

Nature of competitive edges and facilities of their achievement are determined on the basis of strategic management. The strategic management of enterprise a competitiveness, as a system of purposeful influence on elements and processes, that provide forming of competitive edges and development of competition potential of enterprise, is an instrument, that allows to promote efficiency of the use of resources, level of innovative activity, quality of commodities. Totality of present resources and possibilities for development and realization of strategy of development of enterprise determines strategic potential. Strategic potential is the result of combination of productive potential of enterprise with market. Ability to provide proof positions at the market determines potential as competitive. Modern progress of strategic management trends determine the necessity of organizational changes, forming of strategic alliances (networks) and use of management of knowledge for the achievement of competitive edges [8].

An effective strategic management becomes the important condition of providing of competitiveness technologies and innovations.

The modern tendencies of forming of innovative competitiveness determine: increase of role of science and knowledge in a production, increase of scientific content of products, reduction of duration of innovative processes, increase of speed and intensity of processes of diffusion of innovations. A volume and type of innovation must answer strategy of organization. A portfolio of innovations construction is the necessary condition of proof innovation and increase of organization. A radical innovation brings fundamental changes in the competition environment of industry, can show out organization in leaders on the basis of collaboration with external organizations in creation of new initiatives, management favour to the ideas pose of current strategy, resource providing. Half a radical innovation can bring in decision changes in a competition environment, such two-stage innovations are basis of innovative dynamics, zone of considerable potential, it follows that to manage, for this purpose there is a general map of subdivisions of space of business model and technology. An incremental innovation has a considerable value for providing of protecting from competition destruction that diminishes a fate to the market of organization, reduces profitability.

Most facilities and management methods are intended for an assistance to this type of innovations. Blasting innovations focus attention on destruction of competition nature, stop or diminish an increase to the profitableness and potential of creation of values of existent suggestions. There can be strong potential of increase at all innovations, at blasting innovations this potential is the greatest.

An effective management an innovation envisages the management of changes internal sources, by such processes as technological and strategic, determination of business model. The system of strategic management innovations is orientated on a transfer of knowledge, concordance of interests, integration, stimulation of work and studies.

The model of innovation it follows to understand as basis of creation of innovative strategy and development of brief-case that answers general strategy. A case an innovative process frame includes the stages: generation of ideas, previous technological and market researches, conceptual technological and market researches, product, testing development and verification of product, production and leadingout of product to the market, after-sale analysis.

Modern models of "Alpha/Beta Ship", "Time To Market", approaches of swift innovation, Stage/Gate (The "stage/is Passage-way") and Phase/Gate (A "phase/is Passage-way"), watching of projects with the use of the Oregon matrix of the productivity improve the linear model of innovations, accelerating an innovative process reduction of the certain stages, participation of guidance in a management projects, by creation of only command, forming of knowledge about a market situation and possibilities of organization, by application of concentration of resources and integration of participants of projects $[3,6]$.

Conclusions of research and prospect of further works are in this direction.

A competitiveness becomes the determinative factor of successful management and envisages the use of the modern market-adapted methods of management. The conducted analysis of administrative technologies defined the effective tool of management of enterprise the use of that expediently on the basis of situatioonal approach a competitiveness. Achieving of improvement of products, development of technological constituent, forming of competitive edges will provide the effect of synergy on the basis of the successful use of administrative technologies within the limits of strategic management of enterprise a competitiveness. For creation of proof competitive edge it is necessary to determine the priority sources of competitive edges, form perfect competenses, increase a value and create new root competenses, use benchmarking, overcome organizational inertia, in good time to find out out-of-date knowledge, skills, processes.

For strengthening of competition position enterprises are determined events after the certain level of breaks between strategy and potential possibilities of enterprise on the basis of analysis of the systems of strategic position of enterprise. An innovation is the main means of achievement of strategic aims of organizations. Bases of competitive edges of innovations are: radically new product, progressive process or method, marketing innovation of providing of differentiation of suggestion, organizationally-administrative changes.

\section{Conclusions}

A competitiveness becomes the factor of successful management and envisages the use of the modern market-adapted 
methods of management. The conducted modern analysis of administrative technologies defined a tool a competitiveness, use of that expediently situatioonal approach. Achieving of improvement of products, development of technological constituent, forming of competitive edges will provide the effect of synergy on the basis of the successful use of administrative technologies within the limits of strategic management of enterprise a competitiveness. For creation of proof competitive edge it is necessary to determine the priority sources of competitive edges, form perfect competenses, increase a value and create new root competenses, benchmarking, to overcome organizational inertia, in good time to find out out-of-date knowledge, skills, processes.

For strengthening of competition enterprises are determined events after the certain level of breaks between strategy and potential possibilities of enterprise on the basis of analysis of the systems of strategic position of enterprise. An innovation is the main means of achievement of strategic aims of organizations. Bases of competitive edges of innovations are: radically progressive process or method, marketing innovation of providing of differentiation of suggestion, organizationally-administrative changes.

\section{References}

1. Ansoff I. Strategic management: instructional medium / under a release L. Yvenko.Ttranslation from English, Moscow: Economy, 1989. 520 p.

2. Voronkova A. Support of competitive potential of enterprise: instructional medium. Kyiv: Technique, $2000.152 \mathrm{p}$.

3. Davila T., Epshtein M., Shelton R. Working innovation: How to manage her, to measure her and obtain a benefit from her: instructional medium / after a scientific release T. Kozytskoi. Translation from English. Dnipropetrovsk: Balans Biznes Buks, 2007. 320 p.

4. Dykson P. Management marketing. P. Dykson: instructional medium. Translation from English. Moscow: CJSC «Publishing house BYNOM», 1998. 560 p.

5. Druker P. Management aimed at results: instructional medium. Translation from English - Moscow: Technological school of business, 1993. $192 \mathrm{p}$.

6. Maikl L., Vorks D., Khemfyll V. Swift innovations: instructional medium. Translation from English. Kyiv: Companion Group, 2006. 350 p.

7. Porter M. Competition: instructional medium. Moscow: Vyliams, 2005. 608 p.

8. Strategic management: textbook. Translation from English. N. Almazova. Moscow: LLC «Yzdatelstvo Prospekt», 2003. $336 \mathrm{p}$.

9. Tompson A., Stryklend A. Strategic management. Art of development and realization of strategy: textbook for institutions of higher learning. Translation from English. Moscow: Banky and byrzhy, UNITY, 1998. 576 p.

10. Fatkhutdynov R. Competitiveness: economy, strategy, management: textbook. Moscow: Maikl 2000. 351 p.

11. Porter M. Competition: textbook. Translation from English. Moscow: Publishing house « Williams », 2003.496 p.

12. Fatkhutdynov R. Competitiveness: economy, strategy, management: textbook. Moscow: YNFRA-M, 2000. 612 p.

13. Mazaraki A. Trade enterprise: strategy, politics, competitive ability: monograph. Kyiv: Kyiv national university of trade and economics, 2010. P. 125.

14. Balabanova L. A management of enterprises a competitiveness is on the basis of marketing: monograph. Donetsk: Don HUET, 2004. 147 p.

15. Levytska A. Methods of estimation of competitiveness of enterprise: home and foreign going near classification: textbook. Mechanism of adjusting of economy, 2013, № 4, P. 155-161.

16. Karpenko E. Methodological going near the estimation of level of competitiveness of enterprises: textbook. Regionally horizons, 2000, № 2-3. P. 256-259.

17. Altukhov P. Process going near providing of competitiveness of enterprise: textbook. Announcer of economic science of Ukraine, 2005. № 2. P.3-5.

18. Borysiuk I. Basic directions of increase of competitiveness of enterprise [Electronic resource]: Access mode: http://www.nbuv.gov.ua/old jrn/e- journals/PSPE/2012_1/Eryomenko_112.htm.

19. Rybnytskyi D. The modern going is near the evaluation of competitiveness of enterprise: textbook. Scientific announcer UNFU of Ukraine. 2010. Producing 2019. P. 227-230.

20. Litvinova V. Graphic methods of research are in the analysis of level of competitiveness of products: textbook. Biznesinform № 4, 2012 P. 53-56.

21. Dykan V. The methodical going is near the estimation of competitiveness of : instructional medium. Announcer of economy of transport and industry. Series «Economy», 2011. Producing 36. P. 100-105.

22. Yatskovyi D. Modern methods of estimation of competitiveness of enterprise: instructional medium. Announcer of socio-economic researches, 2013, producing 4 (51). P. 183-188. 